\title{
Quebec medical residents threaten strike over hours and pay
}

\author{
n Cite as: CMAJ 2018 February 26;190:E231. doi: 10.1503/cmaj.109-5570
}

Posted on cmajnews.com on Feb.6, 2018.

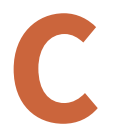
ontract talks between Quebec medical residents and the ministry of health have broken down, with residents warning they are prepared to strike. More than $97 \%$ of members of the province's four medical resident associations recently voted in favour of a possible general strike. In 2016, a similar standoff between government and junior doctors in the United Kingdom resulted in unprecedented strike action.

"Our members are angry," said Dr. Christopher Lemieux, president of the Fédération des médecins résidents du Québec (FRMQ), which represents the four associations. The Ministry of Health has shown a clear lack of respect in its dealings with residents, he said in a French statement. "Now we have no choice but to make ourselves heard."

The residents' last collective agreement expired in March 2015. In September, they agreed in good faith to a more intensive bargaining agenda in the hope of reaching an agreement in principle before the end of the year. However, talks reached an impasse when the government came to the table with an offer that was "virtually unchanged" from a deal it proposed 18 months earlier.

"It is now up to the government to find a solution to the stalemate in which we find ourselves," Lemieux said.

The crux of the impasse is a disagreement over working hours and pay, with Health Minister Gaétan Barrette arguing that residents are working fewer hours today than in the past. However, according to FRMQ data, residents are working as many and often more hours than the 2010 average of 72 hours per week.

Residents also take issue with the number of hours they are being asked to

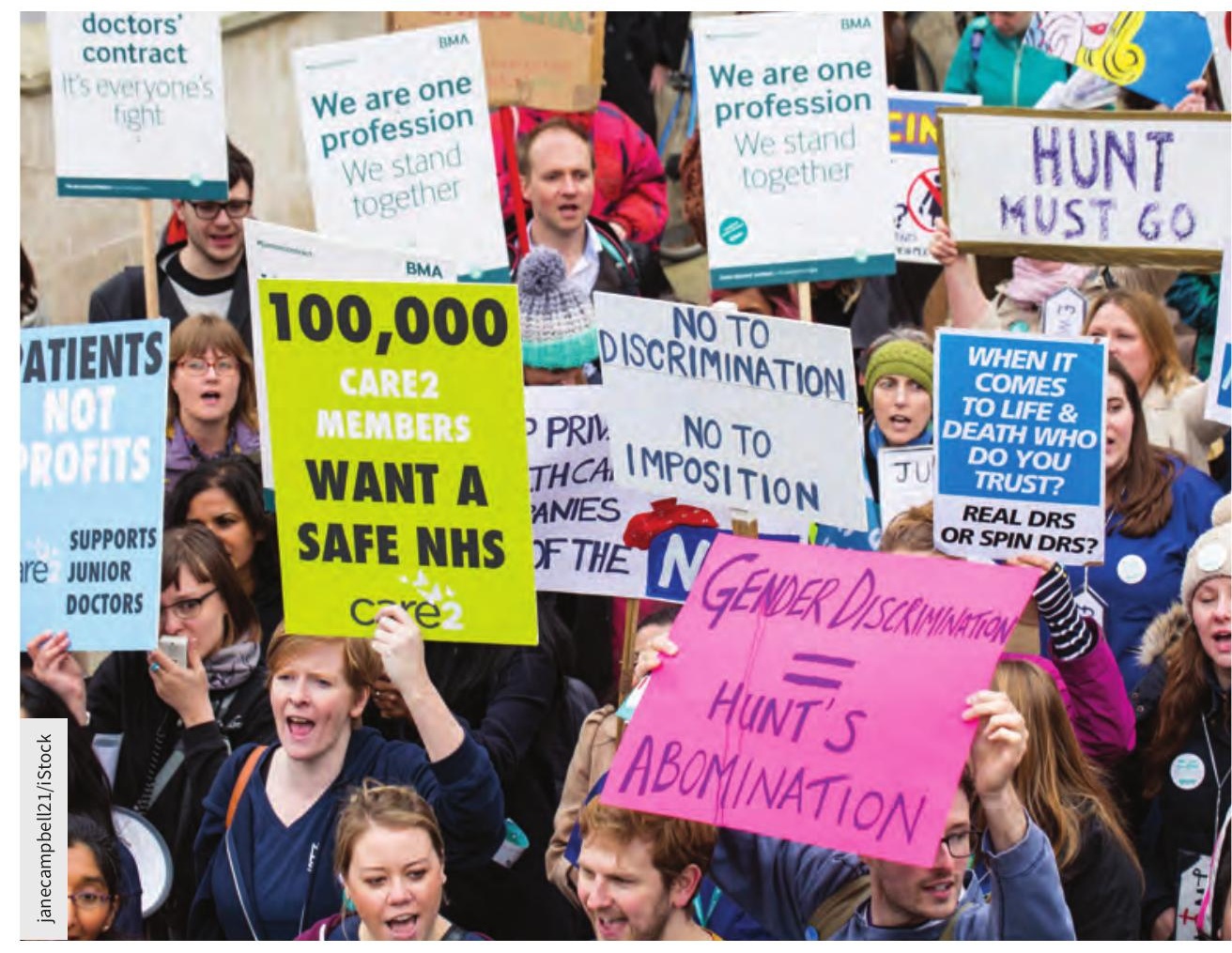

Residents in Quebec may soon strike over working hours and pay, following in the footsteps of junior doctors in the United Kingdom.

work at a time. In 2009, the courts ruled residents should work no more than 16 hours per 24-hour period, but the government is pushing for more shifts and longer hours at night. "It is unacceptable that the department is trying to get our members to work even more," said Lemieux.

Residents want a $17 \%$ increase in remuneration for their efforts. Currently, specialized nurse practitioners with the same number of years of experience earn $27 \%$ more than residents on average. And factoring in 72 hours of work per week, first-year residents earning $\$ 44552$ are making less than the province's new minimum wage of $\$ 12$ per hour.
In addition to a pay raise, residents want a new contract to provide maternity leave and educational leave to give them time to study for certification exams.

The government is still refusing to consider these demands, said Johanne Carrier, FMRQ's communications director. "They propose more work for residents and no pay increase."

The next steps will be determined by the negotiation committee, she said. "Decisions will be made with regard to pressure tactics depending on the government's attitude towards residents and the negotiating team."

Lauren Vogel, CMAJ 